\title{
$\nabla$ \\ Shiitake dermatitis: the first case reported in Brazil ${ }^{*}$ \\ Dermatite flagelada por shiitake, primeiro relato de caso no Brasil
}

\author{
André Ricardo Adriano ${ }^{1}$ \\ Martha Liliana Acosta ${ }^{1}$ \\ David Rubem Azulay²
}

\author{
Carlos Daniel Quiroz ${ }^{1}$ \\ Samantha Rodrigues Talarico ${ }^{1}$
}

\begin{abstract}
Shiitake Dermatitis is often presented as papules and erythemato-violaceous linear streaks. It can be associated with bleomycin treatment, dermatomyositis and shiitake mushroom (Lentinus edodes). There is not any previous report concerning this rare etiology in our country. Shiitake is the second most consumed mushroom worldwide and it can cause flagellate erythema when ingested raw or half cooked. It has a higher incidence in Oriental countries because of their eating habits, this is the first case reported in Brazil, in a male patient that presented a cutaneous rash after consuming this raw mushroom.
\end{abstract}

Keywords: Dermatitis; Erythema; Shiitake mushrooms

Resumo: A dermatite flagelada é caracterizada por pápulas eritematosas lineares com aspecto de "chicotada". A etiologia pode ser associada ao uso de bleomicina, dermatomiosite e shiitake (Lentinus edodes). Este é o segundo cogumelo mais consumido no mundo e pode ser causa de dermatite flagelada quando ingerido cru ou mal cozido. Não há relatos nas literaturas de quadro de dermatite flagelada por shiitake em nosso país, reportamos o primeiro caso no Brasil de um paciente masculino que desenvolveu o quadro após a ingesta desse cogumelo cru.

Palavras-chave: Cogumelos shiitake; Dermatite; Eritema

\section{INTRODUCTION}

Flagellate Erythema is characterized by erythematous violaceous linear grouped papules and sometimes petechiae resembling whiplash marks. ${ }^{1,2}$ It was described for the first time by Moulin in 1970, associated with bleomycin treatment. ${ }^{3}$ Flagellate erythema has also been associated with the use of other drugs such as peplomycin (a bleomycin derivate), inflammatory diseases (dermatomyositis and adult-onset Still's disease) and, most recently, shiitake mushroom (Lentinus edodes). ${ }^{1}$ Shiitake is the second most consumed mushroom in the world and it can cause Flagellate Erythema when consumed raw or half cooked. ${ }^{4,5}$

We report the case for its uncommon etiology and because in a literature review there were no reported cases of flagellate erythema caused by shiitake in Brazil, a country with a varied diet that includes ingestion of large amounts of this mushroom.

\section{CASE REPORT}

Male patient, 30 years old, white, born and living in Rio de Janeiro, RJ, Brazil, complained of intense pruritus followed by disseminated erythematous lesions with onset less than 24 hours before. He had no history of associated diseases, use of any medications or any other associated factors. On the first inspection we noted small erythematous papules and some petechiae that assumed a linear pattern located on the trunk, lower and upper limbs. There were no

\footnotetext{
Received on 03.05.2012.

Approved by the Advisory Board and accepted for publication on 10.07.2012.

* Study carried out at the Dermatology Institute "Professor Rubem David Azulay", Charity Hospital of Rio de Janeiro (Instituto de Dermatologia Professor Rubem David Azulay - Santa Casa da Misericordia do Rio de Janeiro - IDPRDA-SCMRJ) - Rio de Janeiro (RJ), Brazil.

Conflict of interest: None

Financial funding: None

Medical doctor, student of the graduate program in Dermatology at the Dermatology Institute "Professor Rubem David Azulay", Charity Hospital of Rio de Janeiro (Instituto de Dermatologia Professor Rubem David Azulay - Santa Casa da Misericordia do Rio de Janeiro - IDPRDA-SCMRJ) - Rio de Janeiro (RJ), Brazil.

Full professor of the graduate program in Dermatology at the Catholic University of Rio de Janeiro (Pontificia Universidade Catolica do Rio de Janeiro - PUCRJ). Head of Dermatology at Souza Marques Technical and Educational Foundation (Fundação Tecnico Educacional Souza Marques); Head of the Departament of Dermatology at the Dermatology Institute "Professor Rubem David Azulay", Charity Hospital of Rio de Janeiro (Instituto de Dermatologia Professor Rubem David Azulay - Santa Casa da Misericordia do Rio de Janeiro - IDPRDA-SCMRJ) - Rio de Janeiro (RJ), Brazil 
mucosal abnormalities, fever or any other systemic symptoms (Figures 1 and 2). Based on the peculiar rash, the patient was questioned about the ingestion of shiitake and confirmed he had eaten a large amount of raw mushrooms five hours before the cutaneous lesions appeared, leading us to the diagnosis of flagellate erythema due to shiitake ingestion.

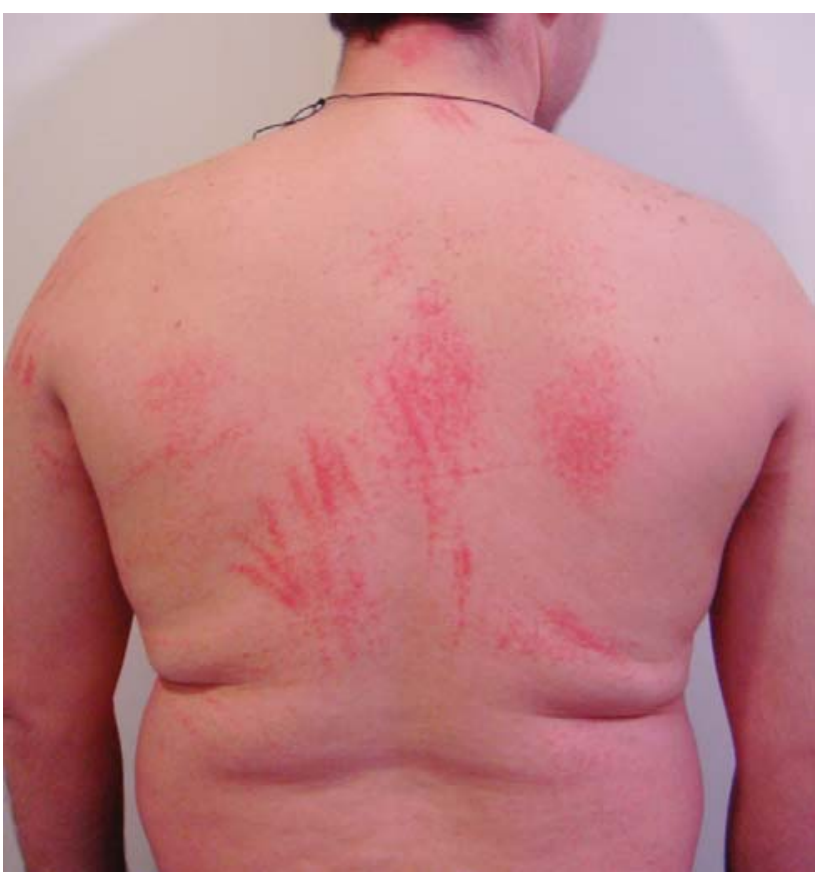

FIGURE 1: Shiitake Dermatitis: clinical features. Small erythematous papules and some petechiae that assumed a linear pattern located on the trunk and arms

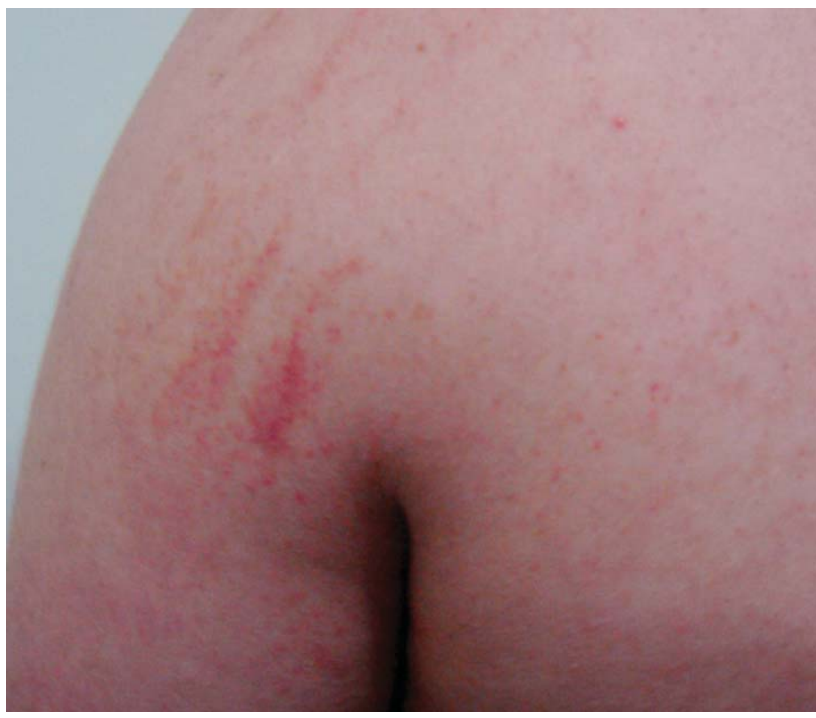

FIGURE 2: Shiitake Dermatitis: clinical features. Small erythematous papules and some petechiae that assumed a linear pattern located on the left shoulder

\section{DISCUSSION}

Flagellate Erythema or Shiitake Dermatitis, also known as toxicoderma or mushroom workers' disease, occurs after eating raw or half cooked shiitake or in people who cultivate the mushroom. ${ }^{1,3}$ Shiitake is the second most consumed mushroom worldwide; due to its polysaccharide properties, lentinan, it is used in Japan for immune system modulation, lowering of blood pressure and serum cholesterol and also as an antitumor adjuvant drug in gastric and colorectal cancer. ${ }^{4,5,6,7}$

Clinical features include very small erythematous papules and eventually petechiae associated with severe pruritus; the act of scratching and Köebner phenomenon lead to the linear groups of these papules. ${ }^{1,45,7}$ The skin eruption appears one or two days after eating the mushrooms and usually involves the trunk, extremities, neck and face. Our patient had similar manifestations a few hours after consuming the mushroom. ${ }^{4}$

Unlike the flagellate erythema due to bleomycin, shiitake dermatitis does not affect mucous membranes nor does it induce pigmentation. ${ }^{1,4}$ Skin lesions tend to disappear in about two weeks but our patient had a faster resolution in only three days and mild hyperpigmentation (Figure 3). Differential diagnosis includes other causes of flagellate erythema such as drug eruptions (bleomycin) and dermatomyositis.

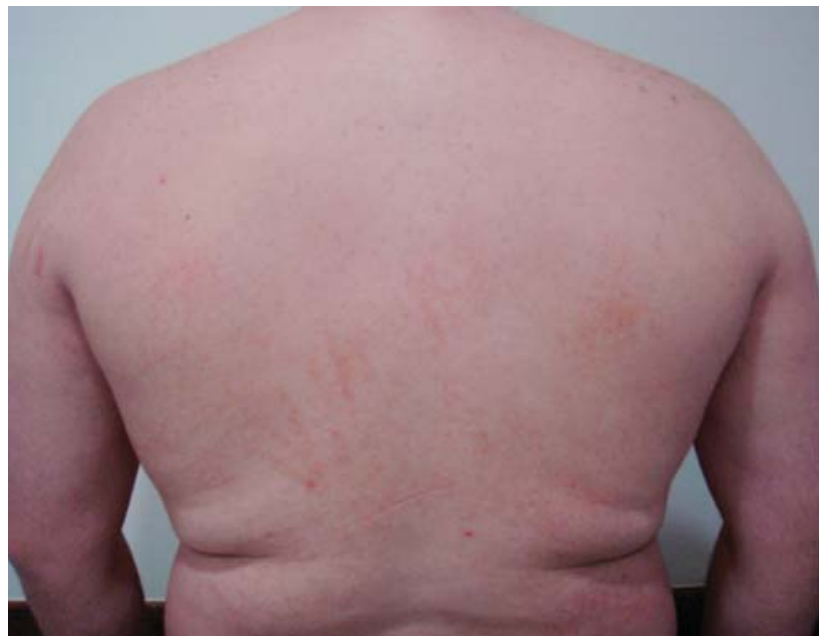

FIGURE 3: Shiitake Dermatitis: clinical evolution. Resolution after three days with mild hyperpigmentation

It is a self-limited condition, therefore the treatment is basically symptomatic. Since pruritus is one of the major complains, it can be controlled with sedatives, antihistamines and topical corticosteroids. ${ }^{3}$

The diagnosis is made through the characteristic history and typical skin lesions. It is important to 
note that there are no specific laboratorial or histopathological findings. ${ }^{4,6,7}$ The histological evaluation of a lesion located on our patient's left shoulder had the following findings: the epidermis was preserved, the dermis showed papillary edema, erythrocyte overflow, superficial and perivascular infiltrates of mononuclear cells, without vasculitis or pigmentary incontinence (Figure 4). In the literature, histologic findings are similar, with nonspecific spongiotic dermatitis. ${ }^{1,4}$

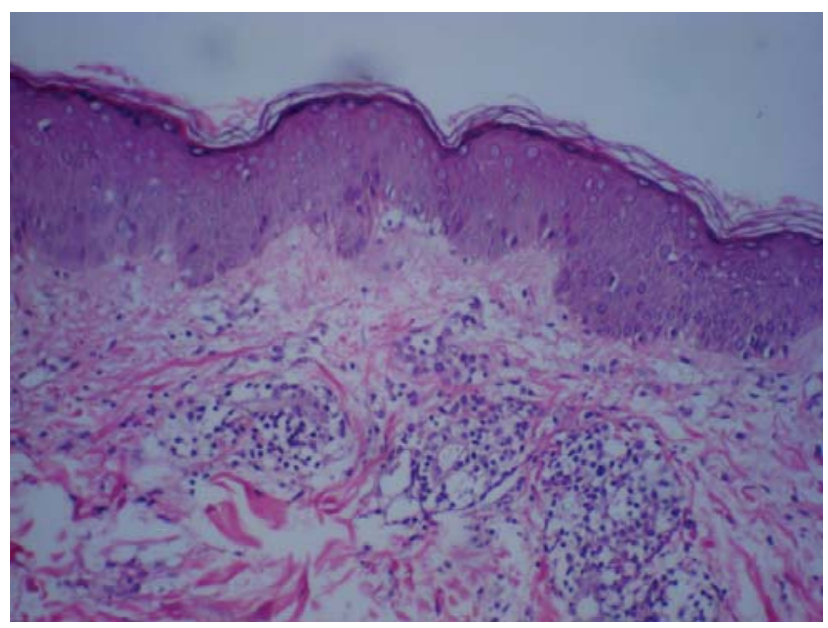

FIGURE 4: Shiitake Dermatitis: histopathology of a lesion located on the patient's left shoulder. Epidermis preserved, dermis showed papillary edema, erythrocyte overflow, superficial and perivascular infiltrates of mononuclear cells, without vasculitis or pigmentary incontinence
The underlying pathogenesis is still not well established; some authors consider that the lentinan could induce a direct toxic skin reaction, other authors submitted their patients to patch and prick tests that came out positive, and they believe that the answer is a late onset hypersensitivity. ${ }^{4,5}$ Based on literature data, there are immunologic and non-immunologic factors involved, the toxic mechanism being the most common.

In Japan and China this dermatitis has a higher prevalence related to the eating habits of the population, but there are few cases reported in the Occident and this is the first case reported in Brazil..$^{5,7}$ Although there is a recent report of a case published in Brazilian literature, the same happened in Germany. ${ }^{8}$

In 1992, Nakamura predicted a gradual increase in incidence of shiitake dermatitis because of the increasing production and ingestion of this mushroom. ${ }^{4}$ There are new reports from Oriental and Occidental countries. Lentinan is a thermolabile polysaccharide, therefore it is important to raise awareness that the ingestion of only well cooked shiitake can prevent this dermatitis. ${ }^{5,7}$

\section{REFERENCES}

1. Yamamoto T, Nishioka K. Flagellate erythema. Int J Dermatol. 2006;45:627-31.

2. Azulay RD, Azulay DR, Azulay-Abulafia L. Dermatologia. 5. ed., rev. e atualizada. Rio de Janeiro: Guanabara Koogan; 2011.

3. Bolognia JL, Jorizzo JL, Rapini RP. Dermatologia. 2. ed., traduzida. Rio de Janeiro: Elsevier; 2011.

4. Nakamura T. Shiitake (Lentinus edodes) dermatitis. Contact Dermatitis. 1992;27: 65-70.

5. Díaz-Corpas T, Mateu-Puchades A, Coll-Puigserver MN, Marquina-Vila A. Flagellate Dermatitis after eating shiitake mushrooms. Actas Dermosifiliogr, 2011; 102:8302.

6. Lippert U, Martin V, Schwertfeger C, Junghans V, Ellinghaus B, Fuchs T. Shiitake dermatitis. Br J Dermatol. 2003;148:178-9

7. Mak RKH, Wakelin SH. Shiitake dermatitis: the first case reported from a European country. Br J Dermatol. 2006;154:800-1

8. Poppe LM, Anders D, Kneitz H, Bröcker EB, Benoit S. Flagellate dermatitis caused by shiitake mushrooms. An Bras Dermatol. 2012;87:465-7.

\author{
MAILING ADDRESS: \\ André Ricardo Adriano \\ Rua Santa Luzia, 206 - Centro \\ 20020-022 - Rio de Janeiro - RJ \\ Brazil \\ E-mail: andrehricardo@gmail.com
}

How to cite this article: Adriano AR, Quiroz CD, Acosta ML, Talarico SR, Azulay DR. Shiitake dermatitis: the first case reported in Brazil. An Bras Dermatol. 2013;88(3):417-9. 